\title{
Decreased Forced Expiratory Volume
}

National Cancer Institute

\section{Source}

National Cancer Institute. Decreased Forced Expiratory Volume. NCI Thesaurus. Code C50524.

A decrease in the fraction of the forced vital capacity that is exhaled in a specific number of seconds. 